\title{
Conveyed Religion
}

A Strategic Communication Proposal for Religious Institutions

https://doi.org/10.21814/uminho.ed.46.17

\section{José Gabriel Andrade}

Communication and Society Research Centre, Institute of Social Sciences, University of Minho, Braga, Portugal

https://orcid.org/0000-0002-9778-5865 



\section{Abstract}

Contemporary society has fostered a period of transformation in religious communication. Globalisation propels a communicated religion that forges a dialogue with its followers and with society as a whole. In this chapter, we aim to describe the existing situation, analysing religions as a social fact in a global society that is shaped by the movement of people and the proliferation of (traditional and new) media channels. From this perspective, religious institutions are viewed as living organisations that must accept the current context and need to develop a strategic communication plan. The chapter begins with a review of a theoretical corpus on religion, communication, and society, intersecting various reflections with theories of strategic communication and crisis communication. It aims to respond to the following question: how can religious institutions use strategic communication in the contemporary world? This is a qualitative investigation, empirically supported by interviews with two prominent figures from the Catholic Church, as a case study. The principal results of this research, based on the observation of contemporary society, include the importance of correct use of new media for strategic communication, and continuous training in order to improve strategic communication plans, that should operate on a continuous basis.

\section{Keywords}

religion, strategic communication, crisis communication, Church, Catholic Church, media, social media

\section{Religion and Contemporaneity: The Media and the Movement of People}

One of the main characteristics of organised religion is that it fosters social integration. For Émile Durkheim (1912/1989), social facts exist regardless of what each individual thinks and does. He identified three differentiating characteristics of social facts: coercivity, exteriority, and generality. On this basis, he considered religion to be a social fact, that is external to the individual, universal, and coercive.

Religion is a solidary system of beliefs and practices related to sacred things, that is, separate, interdicted; beliefs and practices that unite in the same moral community, called the Church, all those who adhere 
to them. The second element that occupies a place in our definition is that it is no less essential than the first is the fact that the idea of religion is inseparable from the idea of Church, this means that religion must be an eminently collective form. (Durkheim, 1912/1989, p. 37)

In this context, ritual can be viewed as a mechanism that reinforces social integration. Durkheim (1912/1989) concluded that the substantial function of religion is the creation, reinforcement, and maintenance of social bonds. As long as society exists, religion will persist, and will effectively reinforce social bonds (Miklos, 2012).

By contrast, Vilém Flusser (1967) claims that contemporary, modernising thinking, which results from the technological era, deforms the fertile religious soil, by suppressing the latent desire for mythical realisation.

Times and religiously poor society, such as the time to end and the technological society, repress and stifle individual capacity for religiosity. ( ...) Another consequence of this repression is the deviation of the religious ardour from the sacred dimension to the boring profanity of the world that results in pseudo-religibilities such as the deification of money and the State. (Flusser, 1967, p. 13)

Flusser (1967) suggested that analysis of the strategic communication of religion in the contemporary era reveals that:

the present moment can therefore be characterised by the attempt, conscious or not, to give new horizons to our religiosity. As individuals and as a society we are looking for a new vehicle to replace traditional religions and open up our latent religiosity. (p. 20)

On the other hand, Arjun Appadurai (1996) discusses global cultural processes, on the basis of two key aspects - social media and global migrations - which, when mutually articulated, impel the imagination as the force that shapes modern subjectivity. Inspired by Benedict Anderson (1991), for whom the emergence of mass print communication had a decisive role in shaping the imagination of the modern nation, spreading it beyond the west, Appadurai proposes that electronic media is achieving the same for the formation of a post-national political imaginary. Its dynamics are characterised by a type of circulation of images and of people that is not confined by local, national or regional borders. Articulated through global communication networks, these media are based on a wide repertoire of 
oral, visual, and aural communication, as well as a varied set of audiovisual genres and languages that connect and allude to one another.

Global migration shapes what Appadurai (1996) calls "the public spheres of the diaspora", or vast and highly diverse, irregularly transnational spaces that have become the crucibles of a post-national political order (Ilharco, 2014). The formation of large imagined communities is driven by electronic media and the images of the world that they project, configuring what Appadurai (1996) called "media landscapes". These help to constitute narratives of the other and proto-narratives of possible lives (Appadurai, 1996). The fluidity and breadth of the circulation of texts in these media foster a cascade effect, which engenders unexpected ethnic implosions in different parts of the world (Appadurai, 1996). How this occurs depends radically on the context in which they take place. For this reason, the repercussions of paedophile abuse in the Catholic Church, anti-Semitic speeches and even the $9 / 11$ attacks have led to varied effects, depending on the places where they have reverberated.

In this context, the principal objective of strategic communication of religious institutions may be the promotion and expansion of dialogue with the world, seeking to preserve their public image in contemporary society. In this way it should be possible to create a differential, which leads society to identify with the institution that forms part of it, while also enabling the latter to attract new "audiences". This type of communication, through the media, must offer a privileged channel between religion and society.

Considering the contributions of Émile Durkheim (1912/1989) on religion, Vilém Flusser (1967) on the media, and Arjun Appadurai (1996) on the movement of people, we realise that contemporary media outlets constitute a "new vehicle", to which Flusser (1967) refers. We propose strategic communication for religious institutions in this dialogue between them and the media. This could be an important tool for sharing knowledge and affirming the democratic space in which we live.

In 2016, a report was presented in the United Kingdom about the place of religion in public life, which revealed a non-positive picture of the relationship between the media and religion. Although misrepresentations in the media generally concern muslims, the biggest complaints are actually presented by christians. Abby Day (2016) argues that the reason for these complaints may be related to fundamental, ancient, and even ontological issues: "recent attention to the mainstream media reveals that the relationship between 
religion and the media seems to be breaking up" (para. 2). In a 2-year investigation into the role of religion in public life, it was reported that virtually everyone involved expressed concern about how religion and belief are portrayed by the media.

There are a number of failings with how religion is represented in the mainstream media, many well documented. The media needs to be held to account, for example, for incorrect stories about particular religious groups. The Independent Press Standards Organisation needs to be tougher and make sure that corrections and retractions are given weight equal to the original erroneous article. (Day, 2016, para. 4)

The strategic communication of religion should reflect a solid knowledge of contemporaneity on the part of those who produce it, given that audiences are no longer passive agents and have become active elements in building communities. As a result, strategic communication must contribute to the creation of its own identity. This identity must include principles that help the faithful and also the entire globalised society to (re)learn the values of a specific religion. In the digital space, will there be a virtual community that can help society?

Anita Day and Guy Golan (2010) have identified increased tension between the faithful and media outlets:

media and religion are two concepts that can be challenging to partner: religion is frequently misrepresented in media for a wide variety of reasons, whether as a result of mistakenly held beliefs or by dramatizing religion to sell newspapers or attract viewers. (p. 120)

According to Draper and Park (2010):

religious stereotypes pervade all forms of media and all types of religions, from the portrayals of Eastern religions seen in Kung Fu Panda and Avatar, which conflate diverse faiths such as Buddhism, Taoism, and Confucianism into one 'mystical' tradition, to the action-packed portrayals of Christianity seen in The Da Vinci Code. At the same time, many religious groups see media as inherently secular and view new media as a threat to traditional religion. (p. 433)

Because of this complex relationship, it is important to be aware of how media outlets often stereotype religion, as well as the most common religious issues covered in contemporary media. 
Bearing in mind that Judaism, Islamism, and, especially, Christianism are the three most prominent religions in European media, the following subchapters will explore issues related to how Christianism, especially the Catholic Church, uses communication strategy. However, since many of these issues are relevant to all religions, these subchapters can also help individuals of other religious backgrounds to better understand the complex ways in which religion is addressed in the media. Thus, we propose to analyse the difference between the strategic communication of religious institutions and not only to deal with informative or persuasive communication.

The digital environment is not a parallel or purely virtual world, but is part of the daily experience of many people, especially the young. Social networks are the result of human interaction, but for their part they also reshape the dynamics of communication which builds relationships. (Benedictus XVI, 2013, para. 5)

\section{Strategic Communication of Religion}

After analysing the role of religion in contemporary society and exploring the dialogue between the media and religion, we will explore the strategic communication of religious institutions, with the aim of identifying possible ways forward. In this context, it is essential to understand the attitudes of religious institutions as well as their positions in relation to media communication. One of the biggest user groups of new media are young people who are also viewed by different religious institutions as a source of hope and, at the same time, a major future challenge. The communication strategy of an institution is essential to determine its success in the transmission of a message, which must promote the values that govern and often inspire people's lives. Currently, there are several ways to communicate and capture society's attention. However, to outline a communication strategy, it is essential to observe the attitudes that individuals demonstrate towards the institution and its communication. We can highlight, as an example, the orientation that the Catholic Church presented in 2013:

at times the gentle voice of reason can be overwhelmed by the din of excessive information and it fails to attract attention which is given instead to those who express themselves in a more persuasive manner. The social media thus need the commitment of all who are conscious of the value of dialogue, reasoned debate and logical argumentation; of people who strive to cultivate forms of discourse and 
expression which appeal to the noblest aspirations of those engaged in the communication process. (Benedictus XVI, 2013, para. 4)

The use of different communicative models has evolved in tandem with the way that communication has been viewed by religious institutions. Until relatively recently, there was what could be identified as an asymmetric one-way model. Communication between the Church and its followers took place during religious services and celebrations or through the publication of documents (letters, commemorative messages, among others) and speeches that expressed the position of the religious institution on a subject and thereby sought to give guidelines to the faithful or celebrate a particular religious event. This enabled us to watch the management of crisis communication in the religious space. But crisis communication is now managed differently. With the development of new information and communication technologies and in the wake of changes introduced by the internet, new forms of participation in public opinion have emerged. Through social networks, which are increasingly popular, such as Facebook, Twitter, or YouTube, individuals can analyse facts, exchange information, and give opinions or criticise a specific comment, news item or event. "The development of social networks calls for commitment: people are engaged in building relationships and making friends, in looking for answers to their questions and being entertained, but also in finding intellectual stimulation and sharing knowledge and know-how" (Benedictus XVI, 2013, para. 3).

Crisis management in communication currently involves paying attention to all the information that circulates about a specific organisation or institution. An institution can experience an unsettled situation and, consequently, have a damaged reputation if it fails to identify and analyse the main news and opinions about itself on the internet. It also needs to know how to monitor and control its pages on social networks, deal with its online audiences, and measure the impact of new technologies on the management of institutional crises. Thus, it is necessary to identify communicative models and schemes used to establish the various types of communication, according to the type of relationship created between the interlocutors.

Is it currently important to observe and identify the type of professions or services that respond to crisis communication management in religion? The importance of this profession is related to the fact that it gives institutions the chance to reposition their image and strengthen it with the public. It is important to understand what structures exist in these institutions and their respective complexity. What is the significance of these 
communication structures within religious institutions? Who is in charge? Which strategies, influences and objectives do they manage? Are there "no answers"? As stated in A Igreja e as Outras Religiões - Diálogo e Missão (The Church and Other Religions - Dialogue and Mission; Arinze \& Zago, 1984):

in interpersonal dialogue, man experiences his limits, but also the possibility of overcoming them, he discovers that he does not have the truth perfectly and totally, but that he can confidently walk towards him, together with other ( ...). The religious experiences and divisions themselves can be enriched in this process of confrontation. (para. 27)

In this manner we will be able to analyse religious institutions as organisations:

organizations are the dominant social units of complex societies, whether industrial or information. Today, we are born in hospitals, we eat in restaurants, we work in companies, public departments, non-profit institutions and, when we die, we turn to the church and the funeral home, all organizations, that penetrate all aspects of contemporary life. (Bilhim, 2009 , p. 19)

According to João Bilhim (2009), "organizational communication covers all forms of communication used by the organization to relate and interact with its audiences" (p. 361). He suggests that communication in organisations fulfils four main functions:

- controls, formally and informally, the behaviour of the members of an organisation;

- motivates employees by informing them about what they should do and by giving them feedback regarding their accomplishment;

- meets the needs of affiliation that every human being has;

- provides the necessary information for decision-making.

Organisations are responsible for their respective environments and all those affected by them. They must therefore take into account that a problem that appears in their midst can lead to unpleasant and risky situations, not only internally but externally. The possibility of a crisis arising in an 
institution is sometimes ignored by it. However, no institution, regardless of its sector of activity, size, reputation, or market share, can be oblivious to possible crises. There are certain organisations which, due to their sector of activity, are prone to potential crisis, for example, oil, chemical, pharmaceutical, nuclear or transport industries. This is also true for the Church as an institution. These organisations, when faced with a crisis, cannot manage it poorly or deny the most susceptible facts, which may highlight their vulnerability. On the other hand, there are organisations that, while not being so vulnerable, seek to be prepared to face and reduce the chances of having to confront major crises. The emergence of crises in organisations is associated with social evolution, which leads to the institutionalisation of organisations from modernity to the contemporary era.

To face a crisis, an organisation must have a balanced working group, including top management and those responsible for different areas, depending on the type of institution, normally including the legal department, production, finance, logistics, resources, and, obviously, communication. This response to crises shows why a company should invest in a crisis management plan, conceptualise the word crisis and divide it into several types (Andrade, 2008).

The image is an important factor in the contemporary era, where information arises and is mixed with entertainment and networked connections, which reduce the organisation's hierarchical levels and foster greater proximity to audiences. In this context of cyberspace, technology is established as a form of demassification, that brings us new possibilities in terms of segmentation, productivity issues, cost and structure reductions, and change of the dissemination processes motivated by the possibility of simultaneous sending information, overcoming geographical and time constraints and new communication processes. The internet is the supreme example of these new capabilities and allows us to identify and systematise some of the new characteristics of this reality. The arrival of new technologies has delivered constant access to all types of information, anywhere in the world. This access has advantages and disadvantages when managing a crisis. Information technologies and new media outlets have accelerated this process. If we used to have very little time to do things, today we have even less. Crisis management was therefore easier 20 or 30 years ago than it is now.

The situational theory of crisis communication, by Coombs and Holladay (2002), is a useful starting point to understand this evolutionary framework and is based on analysis of the organisation's responsibility for the event 
that has generated a crisis. Through the development and occurrences of new events throughout the crisis, the public collects information that they interpret from their point of view and form their own opinions about the organisation. Coombs's (2007) situational crisis communication theory is based on attribution theory which studies how people attribute causes to events and behaviour, that is, how audiences or individuals grant certain and different degrees of blame for the negative events that happen, thereby creating a love or hate relationship with the presumed perpetrator. Situational theory of crisis communication advocates the use of crisis communication strategies to safeguard an organisation's reputation (Coombs, 2007).

In the case of the Catholic Church, Santiago de la Cierva (2008), in his study on crisis management, summarises the concept of crisis:

a crisis is an unstable and uncertain situation, which rises in intensity and causes serious damage to the material and immaterial assets of the organization, and especially to the relationship with its primary public, because they consider the organization in any way responsible for the event. (p. 40)

The same author classifies crises into six main types: natural, technological, and confrontational crises, and crises caused by malevolence, bad management, and illegal conduct. Each type of crisis has its own specificities that the author corroborates with some examples.

Natural crises: they do not have causes attributable to man, consequently the institutional responsibilities are limited to the degree of prudence in foreseeing them and preparing for their arrival. b) Technological crises, caused by the non-use of an industrial technique: a leak of toxic material, collective food contamination, etc. They are more serious because the public attribute them to human errors and because the emotional component is strong: public opinion does not evaluate risk with the same parameters that experts use. c) Crisis of confrontation: caused by a person or a collective that opposes the institution in a public way, and which claims to mobilize the population to prevent the activities of the institution or reduce its operational scope. d) Crisis of malevolence: caused by illegal or external criminal interventions, such as kidnapping, robbery, theft of developing projects, etc. e) Crises resulting from incorrect values in the organization: they occur when executives seek a high short-term return at the cost of social benefit and the expense of the other 
public in the organization: for example, when the board of directors of a company decides to disproportionately high fees. f) Crisis due to illicit conduct by its managers: for example, the violence of a teacher against minors in his charge. In journalistic terms: "scandals", illegal behavior that provokes outrage and reproach in public opinion. (Cierva, 2008, pp. 41-42)

Santiago de la Cierva (2008) considers that it is necessary to have a crisis preparation process within the Church, in other words, a well-structured crisis plan, identical to that of a company. This plan must then be followed literally by the Church before, during, and after the crisis: "the crisis plan can be defined as the operational program that an institution must follow during and after a crisis to avoid or mitigate its negative effects" (Cierva, 2008, p. 144). Indeed, the Church seems to be already taking its first steps in the field of crisis management. A "Church Response" space is already available on the Vatican website, where the Church responds in the first person to sensitive issues that may harm the Church's reputation, in particular the question of child abuse. Santiago de la Cierva (2008) stresses the importance of the website for crisis management: "the website is institutional is certainly useful, with a curable use: badly set up, instead of helping to solve problems it could do - for its instant diffusion and worldwide scope - more harm than good" (p. 196).

\section{Perspectives of Strategic Religious Communication: The Catholic Church}

Participation in the project "Organizational communication media training for church institutions" developed at the Portuguese Catholic University between 2012 and 2013, made it possible to collect the interviews that we present herein as empirical material for this analysis. The observation of these interviews originated a master's dissertation in the field of communication sciences at the Portuguese Catholic University entitled: Gestão e Comunicação de Crise na Igreja Católica: Uma Reflexão no Contexto da Sociedade de Informação (Crisis Management and Communication in the Catholic Church: A Reflection in the Context of the Information Society; Pereira, 2014). From the set of interviews that were carried out on the Portuguese reality in the strategic communication of the Catholic Church, we selected the material of the empirical investigation those provided by two senior figures responsible for communication of the Catholic Church, in Portugal. They are Pedro Gil, spokesman for Opus Dei, the international leader in the 
Catholic Church's Communication, and Father Nuno Rosário, director of the Voz da Verdade newspaper of the patriarchate of Lisbon, both of whom are profoundly aware of the Portuguese context (Pereira, 2014).

In 2005, José Marques de Melo (2005) highlighted the relations between the Catholic Church and the field of communication. In this sense, it is important to identify, in a synthetic manner, the three phases, defined in the path of the Church's relationship with communication. These phases are located in the context of the new instruments of symbolic reproduction, that began with the invention of the printing press in the 15th century, whereby new means of transmitting knowledge have been absorbed, used, and instrumentalised according to the communication paradigm that prevailed at the time. These phases observe the historical changes that have forced transformations in the organisational structure, both in society and in the Church, highlighting the institution's confrontation with the media (Melo, 2005).

The first phase is characterised by the Church's behaviour oriented towards the exercise of censorship and repression. It corresponds to an extensive and intense period, implicitly related to the Inquisition. During this period, the Church was the intermediary between the production of knowledge (not just the theological) and its diffusion in society.

The second phase is related to profound changes determined by the acceptance, albeit somewhat reluctantly, of new media. Control over the press, surveillance over cinema, and radio marked the Church's trajectory during this period. However, society, which was changing rapidly, impelled the Church to "adapt to the new times", forcing ecclesial behaviour to change, and beginning to accept electronic media, while maintaining its misgivings (Melo, 2005). The Church began to use the media to spread its messages.

Finally, there is the third phase, that is developing at a fast pace, associated with the speed of social and technological changes. During this period, it has become imperative for the church "not to fall behind" and with an urgent need to adapt to the contemporary world, that emerges from Vatican II (Melo, 2005). Concerning communication, there has been a sudden change in direction, when compared to the second phase. The Church assumes that it is necessary to evangelise and use modern means of communication. It admits that the technology of electronic reproduction can increase the penetration of the ecclesial message. The strategic communication of religion must be able to create a differential, which leads followers to identify with 
the institution of which they are part and attract new audiences. This type of communication must be a privileged channel between the Church and society, through the media. The Church has shown its concern towards the ambivalent role of the media, since it can be used for good or evil. This perception has been maintained over the years and is expressed in several texts produced by the Church. Is the main change the way that this issue is now being addressed? In the past, the Church used methods, which today are unacceptable, such as censorship. However, today's discourse takes the form of advice, trying to raise awareness in society without imposing values. Recent documents, related to problems in the communication field, reiterate the need for society to be at the centre of all activities in the area of communication, and all technological advances are emphasised, with their due dignity. The Church, whenever it deems this to be necessary, has acknowledged criticisms and denunciations of errors and abuses, enticing society to foster a debate on the role of the media and its influence in the different areas of human life. It is believed that the reflections that the Church has developed can enrich the field of communication, constituting documents that deserve to be known and discussed by society in general.

For Pedro Gil, the role of communication in the Church is broadly identical to that of a company, it must have a well-defined communication structure, based on values (Pereira, 2014). He also highlights several forms of communication that are evident in the daily life of the Catholic Church.

The role of Communication within the Church is very similar to the performance in any other organization. The priority task is that all members are in tune with what the Church is and represents. The Church has to make its message public, having external communication and it must develop the same type of actions, as any other organization does. I emphasize that there are organizations that understand communication as advertising, but there are many other organizations that propose values and ideas, where advertising can appear, but in a more conscientious manner. (Pereira, 2014, p. 59)

This representative of Opus Dei uses the structure of the Church to explain how communication is established; he also stresses the lack of unification of the organization and the responsibility that each part plays in relation to communication.

According to Pedro Gil: 
the communication of the Church depends on how the Church is constituted, although it is one, the Catholic Church is far from being a unified organization, the Church is a set of small constituencies, small units like a Diocese (...) which means that there must be about 4,000 units in the entire Church, each one with maximum responsibility within its constituency. Communication depends on the policy of each of these units. Therefore, the Church is (not organised) in communication, the Dioceses are very unequal, some have no one exclusively connected to communication, but there are also Dioceses such as the Diocese of Chicago that has 30 people working in the communication department. In Rome, the government of the Church is merely of coordination, it does not even establish guidelines for the various Dioceses. There is a spokesman for the Pope and a press room that declares to journalists. (Pereira, 2014, p. 60)

In the opinion of Pedro Gil, communication does not occupy a place of relevance within the Church, and should be a more organised area and with strong support for the external world:

in the various Dioceses, communication still does not occupy a priority position, communication ends up happening because it is inevitable, whenever things happen that we need to take a stand for, there is always a spokesman, there are always journalists who, when doing their job, end up being able to talk to someone. Communication, as the Church's response to external requests exists, but it is not a priority tool for proactive actions. What exists is an awareness that communication takes place mainly through the means of information that the Church itself has. I question this view. I believe that the media are intermediaries between social agents and the public and have an autonomy that must be respected. (Pereira, 2014, p. 60)

About the evolution of communication, Pedro Gil considers that there are many points to be explored. Once again, communication pursues new trends, but without a strategy defined by the different dioceses:

the trend of evolution of the Church that is verified is once again driven by the force of reality rather than by a strategy. It is trying to make the most of these new technological and digital realities of the relationship between people, but I would say that while it is true that this is an emerging reality, it is also necessary to find proper languages, the most important role of communication is to ensure that 
Church officials have a personal relationship with the main players in the surroundings of the cultural world, including the media. There is a whole field of institutional communicative relationship to be explored, I would even say that it is like an unspoiled desert. (Pereira, 2014, p. 61)

Father Nuno Rosário considers that the role of communication is very important: "the Church has long sought to use the media to get its message across. On the other hand, in addition to being an instrument of evangelisation, it is also an instrument for spreading the Church's initiatives and activities" (Pereira, 2014, p. 58).

Communication within the patriarchate of Lisbon is achieved through various means of communication that are available to the Church. It is through these same channels that connections are often made between the Church and public opinion. According to Father Nuno Rosário:

communication in the Patriarchate of Lisbon is achieved through the official organ of the Diocese, which is a magazine called "Catholic Life", then there is a media outlet (let's call it an office) that corresponds to the Diocese newspaper, "Voz da Verdade". There are also other types of means of communication, we use the internet, social networks and the Patriarchate's institutional website. There is another way of communication, namely internal with the priests of the Diocese through a mailing list with journalists, as the communication department contacts the media to produce texts from the bishop's homily. There is also a personal contact that is currently achieved in certain situations. (Pereira, 2014, p. 58)

The Church has clear objectives for the message that it intends to pass, both internally and externally, one of the main objectives is to reach public opinion, for Father Nuno Rosário:

the communication is achieved in a very organised manner, territorially (locally) with the objective above all to communicate, as I said at the beginning, to get information. To reach public opinion, one seeks in some way, to convey echoes of what the Church is. Demonstrate the life of the Church, what does the Church do in society? What does the Church do in the world? And how the Church is present in our daily life. (Pereira, 2014, p. 59) 
Father Nuno Rosário confirms the existence of a department dedicated to the area of communication in the diocese of Lisbon: "in the Diocese of Lisbon there is a communication department that seeks to manage this type of news, in liaison with the Bishop. The department never acts independently, all the news that is issued receives prior approval from Bishop" (Pereira, 2014, p. 65).

Regarding social networks, Father Nuno Rosário believes that they have brought rapid dissemination of information: "social networks have made information spread quickly. But you never know who is behind a social network and information can be manipulated" (Pereira, 2014, p. 65). On this matter, Pedro Gil shares the same opinion as Father Nuno Rosário, and defends that believers and non-believers should be informed about everything that goes on inside the Church, while highlighting other relevant issues for general reflection:

all people need to be informed, not only about the most relevant or impacting news. It is not the dimension of the event that matters. The Church continues to say that God is alive and that He spoke to Men and the question that the world asks is whether this makes sense, that is the question that has to be answered. More than knowing how many alms the Church has received (this is the policy of knowing everything about the Church), the important thing is to know whether the Church is still relevant, and why? Rethinking whether we are no longer interesting. (Pereira, 2014, p. 65)

For Pedro Gil, the response to crisis communication is often not the most adequate:

we have a dispersal of communication responsibilities and we do not always have the task of communication entrusted to whoever has that responsibility. The answer is given spontaneously and sometimes forgetting the most elementary rules of communication, the instinctive answer is not always the one that helps to originate the answer. Poorly answered communicative crises are often a key opportunity to be more careful with communication. I know that some people have the task of consulting various opinions and then the answer that comes out is not the most appropriate one. (Pereira, 2014, p. 65)

In regard to crisis communication management, Pedro Gil identifies which solutions are most suitable to defend against a crisis problem: 
it is advisable in institutions to have a crisis committee, a very well-defined group of people who know that on the day that there is a problem, they have to gather to resolve the issue. The first step in a good defence is to have already determined who takes the lead, who will be the spokesperson. (Pereira, 2014, p. 65)

In social networks the position must be carefully selected, Pedro Gil emphasises the importance of an assertive social media manager:

it depends on the angle, there are many groups, hatred and much else. We have no exact information as to whether it has an impact, but it is to be hoped that the Church will be parallel to the echoes of the negative news coming from other institutions. Although whenever negative news comes out, we know what kind of groups can expect a particular reaction. The social media manager is important to mitigate such situations. (Pereira, 2014, p. 66)

\section{For a Movement of People With (Re)Acknowledgement of the Media and Communication Management}

Religious communication must, therefore, reflect a solid knowledge of reality on the part of those who produce it. How to observe the "audiences" that cease to be passive and become active elements in the construction of communities, must be helped to create their own identity. This should include principles that help the faithful, even in a globalised culture, to maintain the values of a certain religion.

Al Ries and Jack Trout (1980/2002) define religious communication as "the essence of any religion" (p. 181), in their book Positioning: The Battle for Your Mind. According to these two authors, the way that "the clergy applies the theory of communication to the practice of religion will have an important influence on how religion affects the congregation" (Ries \& Trout, 1980/2002, p. 181). For several years, the Catholic Church has come to recognise that it had concrete communication problems, and that it was "disorganized, at best" (Ries \& Trout, 1980/2002, p. 181).

After the Second Vatican Council, we witnessed an unprecedented opening of the Church to society, which has improved its communication skills. These problems were portrayed in the interviews that supported this analysis, in a more or less pronounced manner. The interviewees assumed that it is a problem rooted within the Church. With the repositioning of the Church 
in society, followers have begun to question what its new role will be. Although a moral position was still recognised, this lack of definition has caused some members of the congregation to abandon the Church in favour of other interests. The Catholic Church itself has experienced difficulties in carrying out its mission, asking the question about its role in the modern world. The emergence of crises is intertwined with social evolution, which often leads to the institutionalisation of organisations in the transition to the information society. In the Church's connection to society, religion has undergone an improvement in communicative skills.

In today's society, networked, can the virtual community truly help someone? To what extent do we let the media take on a responsibility that they cannot help. To paraphrase Durkheim (1912/1989), Flusser (1967), and Appadurai (1996), we live in a multi-religious world, and based on this reality, further studies on the relations established between the various religions and the media may arise.

Any organisation is constantly liable to experience an internal or external crisis. It is therefore essential to have a well-designed crisis communication plan, ready to be implemented. The crisis is unexpected, threatens values, and can jeopardise an organisation's credibility and reputation. In this field, the Church is also no exception, as has been mentioned throughout this paper. The Catholic Church is increasingly seen as an organisation. However, concerning the principles of crisis management, the Church follows divergent paths.

Currently, with greater use of the media by the Church, among others, there is already significant participation of the faithful, who have inclusively assumed critical positions. It is common to read documents, websites, or blogs, that include comments on decisions made by members of the Church and even comments by those who constitute it.

Crisis communication plays a strategic role in recovering the institutional image of religion and its reputation because, by working on the perception of its followers, it helps them to look at this process perpetually.

It is important to emphasise the importance of the existence of officials who are responsible for the communication area so that it is achieved in an organised, targeted manner, and to understand the phenomena of communication. Pope Francis said that "in a world like this, media can help us to feel closer to one another" (Francis, 2014, para. 2), adding that "it is not 
enough to be passers-by on the digital highways, simply connected; connections need to grow into true encounters. We cannot live apart, closed in on ourselves" (Francis, 2014, para. 7).

The strategic communication that is made by religious institutions does not acquire the dimensions of that practiced in companies. In the dissemination of the word or message of the religion, word of mouth has a considerable weight in the dissemination of a certain religious offer, as well as the communication made by the members of the organisation. No organisation is immune to crisis. For this reason, crisis management must be very well integrated into the strategic planning of organisations, religious institutions must be guided by these guidelines so that their communication is efficient when facing crises. This moment of crisis management always generates emotions and weaknesses, where digital media and, mainly, social media have a greater impact, increasing speed of transmission in times of crisis, which can cause problems because the institution is not always sufficiently prepared. Religion is invited to be structured for a quick response, which is transparent and true, even if it does not have all the information at first. The important thing is to show that there is a commitment to reversing the situation. In 2020, Pope Francis remarked:

in an age when falsification is increasingly sophisticated, reaching exponential levels (as in deep fake), we need wisdom to be able to welcome and create beautiful, true and good stories. We need courage to reject false and evil stories. We need patience and discernment to rediscover stories that help us not to lose the thread amid today's many troubles. We need stories that reveal who we truly are, also in the untold heroism of everyday life. (para. 7)

The media and religious institutions are largely comprised by passionate and hard-working people who believe in what they do. Religious belief is understood as something that is more profound and meaningful than just signing a series of statements about the existence of the divine or determining press regulations. But belief in religious institutions or press standards means trusting these sources and acting in specific ways because of that conviction. The idea remains that the statements made by religious institutions are sacred, especially when they can understand the "sacred". When two different groups of people claim that their truth is non-negotiable, problems inevitably ensue. Therefore, it is necessary to have a form of religious literacy, and it is essential to have strategic communication plans for religion, which are less focused on the exchange of facts and more on high quality dialogue. 
It can therefore be concluded that believers must be guided, through conferences, courses, round tables and congresses, that present studies or critical analyses made by experts, or even through academic training, so that believers can develop their critical views on the various themes of strategic communication. At the same time, the various religious institutions must be ready to give all the necessary collaboration in the transmission of information, communication, requests required to deal with religious issues. It is important to emphasise that a communicated religion is the proposal for the contemporary era.

\section{Acknowledgments}

This work is supported by national funds through FCT - Fundação para a Ciência e a Tecnologia, I.P., under the project UIDB/00736/2020.

\section{References}

Anderson, B. (1991). Imagined communities: Reflections on the origin and spread of nationalism. Verso.

Andrade, J. (2008). Comunicando e gerindo crises - 0 envolvimento da Portugal Telecom no "mensalão". In M. L. Martins \& M. Pinto (Eds.), Comunicação e cidadania - Actas do $5^{\circ}$ Congresso da Associação Portuguesa de Ciências da Comunicação (pp. 235-247). Centro de Estudos de Comunicação e Sociedade.

Appadurai, A. (1996). Dimensões culturais da globalização (T. Costa, Trad.). Teorema.

Arinze, F., \& Zago, P. M. (1984, June 10). A igreja e as outras religiões - Diálogo e missão. Vatican. http://www.vatican.va/roman_curia/pontifical_councils/interelg/documents/rc_pc_interelg_ doc_19840610_dialogo-missione_po.html

Benedictus XVI. (2013, May 12). Message of his holiness Pope Benedict XVI for the 47th world communications day: "Social networks: Portals of truth and faith; new spaces for evangelisation.". Vatican. https://www.vatican.va/content/benedict-xvi/en/messages/communications/documents/hf_ben-xvi_mes_20130124_47th-world-communications-day.html

Bilhim, J. (2009). Teoria organizacional: Estruturas e pessoas. ISCSP.

Cierva, S. (2008). La comunicazione di crisi nella chiesa. Edusc.

Coombs, W. (2007). Crisis management and communications. Institute for Public Relations, 4(5), 1-14. https://instituteforpr.org/crisis-management-and-communications/

Coombs, W., \& Holladay, S. (2002). Helping crisis managers protect reputational assets: Initial tests of the situational crisis communication theory. Management Communication Quarterly, 16(2), 165-186. https://doi.org/10.1177/089331802237233 
Day, A. (2016,August 27). The conflict between religion and media has deep roots. LSE BPP. https:// blogs.Ise.ac.uk/politicsandpolicy/the-conflict-between-religion-and-media-has-deep-roots/

Day, A., \& Golan, G. (2010). In God we trust: Religiosity as a predictor of perceptions of media trust, factuality and privacy invasion. American Behavioural Scientist, 54(2), 120-136. https:// doi.org/10.1177/0002764210376314

Draper,S., \& Park,J.Z.(2010). Sunday celluloid:Visual media and protestant boundaries with secular culture.Sociological Spectrum,30(4),433-458.https://doi.org/10.1080/02732171003641032

Durkheim , É. (1989). As formas elementares da vida religiosa: O sistema totêmico na Austrália (J. P. Neto, Trans.). Paulinas. (Original work published 1912)

Flusser, V. (1967). Da religiosidade: A literatura e o senso de realidade. Comissão Estadual da Cultura.

Francis. (2014, June 1). Message of Pope Francis for the 48th world communications day: Communication at the service of an authentic culture of encounter. Vatican. https://www.vatican.va/content/francesco/en/messages/communications/documents/papa-francesco_20140124_messaggio-comunicazioni-sociali.html

Francis. (2020, January 24). Message of his holiness Pope Francis for the 54th world communications day: "That you may tell your children and grandchildren" (Ex 10:2). Life becomes history. Vatican. http://www.vatican.va/content/francesco/en/messages/communications/documents/ papa-francesco_20200124_messaggio-comunicazioni-sociali.html

Itharco, F. (2014). Pós-sociedade. A sociedade pós-literária, pós-nacional, pós-democrática e pós-ocidental. Imprensa Nacional Casa da Moeda.

Melo, J. M. de. (2005). Comunicação eclesial: Utopia e realidade. Paulinas.

Miklos, J. (2012). Ciber-religião. Ideias \& Letras.

Pereira, P. (2014). Gestão e comunicação de crise na Igreja Católica: Uma reflexão no contexto da sociedade de informação [Master's thesis, Universidade Católica Portuguesa]. Repositório Institucional da Universidade Católica Portuguesa. http://hdl.handle.net/10400.14/17835

Ries, A., \& Trout, J. (2002). Posicionamento: A batalha por sua mente (E. F. Pereira, Trans.). Makron Books. (Original work published 1980) 